\title{
Helioseris cucullata as a host coral at St. Eustatius, Dutch Caribbean
}

\author{
Bert W. Hoeksema ${ }^{1,2}$ - Mick van Beusekom ${ }^{1,3}$ - Harry A. ten Hove ${ }^{1}$.

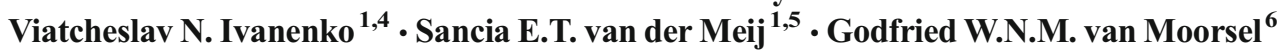

Received: 31 August 2016/Revised: 26 October 2016 / Accepted: 27 October 2016 / Published online: 22 November 2016

(C) The Author(s) 2016. This article is published with open access at Springerlink.com

\begin{abstract}
In order to demonstrate how scleractinian corals contribute to marine biodiversity by their host function, information on associated fauna was gathered during a biological survey at St. Eustatius, eastern Caribbean. This knowledge is especially urgent for a host coral such as Helioseris cucullata (Agariciidae), which has undergone strong declines in abundance at various Caribbean localities and has a poor record of associated fauna. New records of $H$. cucullata as host are presented for the coral gall crab Opecarcinus hypostegus (Cryptochiridae), the Christmas tree worm Spirobranchus giganteus (Serpulidae) and an unidentified serpulid tube worm of the genus Vermiliopsis. A second association record is reported for the coral barnacle Megatrema madreporarum (Pyrgomatidae). Coral-associated copepods were not found on $H$. cucullata despite a search for these animals. The new records were compared with previous records of other host coral species that showed elements of the same associated
\end{abstract}

Communicated by J. Davis Reimer

Bert W. Hoeksema

bert.hoeksema@naturalis.nl

1 Naturalis Biodiversity Center, P.O. Box 9517, 2300 RA Leiden, The Netherlands

2 Institute of Biology Leiden, Leiden University, P.O. Box 9505, 2300 RA Leiden, The Netherlands

3 Institute for Biodiversity and Ecosystem Dynamics, University of Amsterdam, P.O. Box 94240, 1090 GE Amsterdam, The Netherlands

4 Department of Invertebrate Zoology Biological Faculty, Lomonosov Moscow State University, Moscow 119992, Russia

5 Oxford University Museum of Natural History, Parks Road, Oxford OX1 3PW, UK

6 Ecosub, P.O. Box 126, 3940 AC Doorn, The Netherlands fauna. The present findings indicate that new discoveries concerning Caribbean coral reef biodiversity can still be made during field expeditions by targeting the assemblages of associated fauna of specific benthic host species.

Keywords Associated fauna $\cdot$ Copepod $\cdot$ Coral barnacle . Coral reefs $\cdot$ EDGE species $\cdot$ Gall crab $\cdot$ Serpulid

\section{Introduction}

Helioseris cucullata (Ellis and Solander, 1786) (Scleractinia: Agariicidae) is a foliaceous reef coral with a Caribbean distribution. It represents a monospecific clade that is separate from the predominantly Indo-Pacific genus Leptoseris, with which it was previously classified (Kitahara et al. 2012). Its calices are arranged in between concentric, discontinuous, lopsided ridges, giving its upper surface a wave-like appearance, for which it has been nicknamed Sunray lettuce coral (Humann and DeLoach 2013).

Live specimens have been recorded from lower reef slopes, including the mesophotic down to $99 \mathrm{~m}$ depth (Bak 1975; Kahng et al. 2010; Bongaerts et al. 2013; Jaap 2015; Hoeksema and Van Moorsel 2016). Dead fragments of recently deceased colonies have been dredged from $>150 \mathrm{~m}$ depth (Santodomingo et al. 2007). At some localities, declines in its abundance have been recorded, especially reduced densities of its recruits over time, which eventually affect whole populations (Hughes and Tanner 2000; Vermeij et al. 2011; Miller et al. 2016). This is consistent with provenance data available from $H$. cucullata specimens in the coral collection of Naturalis Biodiversity Center (Leiden, The Netherlands). Seven $H$. cucullata corals in this collection were sampled in the 1970s from lower reef slopes (12-30 m depth) at three localities in Curaçao, where the species has become rare or 
absent since then (Hoeksema pers. observ.). These findings are corroborated by observations at other localities on the same island by Vermeij et al. (2011), who linked a drastic decrease in the density of juvenile $\mathrm{H}$. cucullata to a decline in reef health. Earlier assessments by Aronson et al. (2008), who stated that no large declines have been observed and that the conservation status of $H$. cucullata in the IUCN Red List of Threatened Species should be considered of "least concern", are therefore in need of a reevaluation. In view of the recently recognized phylogenetic position of $H$. cucullata (Huang 2012; Kitahara et al. 2012, 2016), such a reconsideration may also result in a higher conservation priority based on its EDGE score (Evolutionarily Distinct and Globally Endangered; see Curnick et al. 2015).

Corals not only contribute to reef biodiversity by themselves, but also serve as host for assemblages of associated fauna (Scott 1987; Stella et al. 2011) that could contain hostspecific species (Hoeksema et al. 2012). Hence, the protection of particular corals is also important for the conservation of entire reef faunal assemblages (Huang et al. 2016). Knowledge of coral associates is also relevant, since most of them are filter-feeding heterotrophs. Consequently, their abundance on reefs may also be indicative of environmental stress caused by eutrophication and sedimentation (Risk et al. 2001; Scaps and Denis 2008; Samimi Namin et al. 2010).

Recent studies in the Indo-Pacific targeting scleractinian species for associated fauna have resulted in new host records for small or hidden species of, for example, parasitic snails (Gittenberger and Gittenberger 2011; Gittenberger and Hoeksema 2013), benthic ctenophores (Hoeksema et al. 2013; Alamaru et al. 2016), copepods (Ivanenko et al. 2014), hydroids (Montano et al. 2014, 2015a, b), cryptobenthic fish (Bos 2012; Bos and Hoeksema 2015), and commensal shrimps (Fransen and Rauch 2013; Ďuriš and Lin 2016). New host records were also obtained during recent studies of Scleractinia-associated fauna in the Caribbean. They concern, for instance, gall crabs (Van der Meij 2014), serpulids (Hoeksema and Ten Hove 2016), commensal shrimps (Brinkmann and Fransen 2016), hydroids (Montano et al. 2016), and corallivorous snails (Potkamp 2016).

Probably due to its relatively deep distribution range compared to many other reef corals ( $>12 \mathrm{~m}$ depth) and its rarity, only two cases appear to be available concerning $H$. cucullata as a host coral (see Stella et al. 2011). One mentions a single H. cucullata coral as host of a corallivorous snail, Coralliophila galea (Dillwyn, 1823), erroneously referred to as C. abbreviata Lamarck, 1816 (Miller 1981). The other one mentions several $\mathrm{H}$. cucullata corals showing infestations by coral barnacles (Scott 1987). Recent studies at Curaçao, in which scleractinians were systematically examined for associated coral gall crabs and serpulid worms, also failed to discover H. cucullata specimens as host corals (Van der Meij 2014; Hoeksema and Ten Hove 2016). Therefore, for the present study it was hypothesized that field surveys targeting coral species with a poor reputation as host coral, such as in this case H. cucullata (Scott 1987), would result in new discoveries of associations. During a recent marine biodiversity survey at St. Eustatius (eastern Caribbean; Hoeksema 2016), H. cucullata appeared to be relatively common (GarcíaHernández et al. 2016; Hoeksema and Van Moorsel 2016). This offered an opportunity to study its associated fauna, the topic of the present report.

\section{Material and methods}

During the marine biodiversity survey of St. Eustatius, in June 2015, stony corals were inspected for the presence of associated fauna by use of the roving diver technique (Hoeksema and Van Moorsel 2016). St. Eustatius is located in the eastern Caribbean, where it has a wave-exposed coastline at its eastward Atlantic side and a sheltered coast at the western, Caribbean shoreline (Hoeksema 2016). The maximum depth for the observations was $30 \mathrm{~m}$ due to SCUBA safety regulations. Among a total of 39 dives of approximately $60 \mathrm{~min}, 36$ dives exceeded $12 \mathrm{~m}$, covering the preferred depth range of $H$. cucullata. Clearly visible associated macrofauna was photographed, sampled, and stored in $96 \%$ ethanol for further examination. In a survey of coral-associated copepods, in as many coral species as possible, four Helioseris colonies were examined for the presence of associated copepods (Ivanenko 2016). The corals were collected and isolated in plastic bags underwater; in the laboratory, ethanol was added to the bags (adjusting solution 10\%), and the hosts were kept in the solution for 20-30 min; then the symbionts were shaken and the residue with anaesthetized copepods was passed through a fine sieve (mesh size $60 \mu \mathrm{m}$ ). The corals were also examined for presence of copepods living in galls or polyps. The dry coral collection of Naturalis Biodiversity Center was inspected for additional associations involving $H$. cucullata. Collection numbers are coded "RMNH Coel." for specimens in the collection of the former Rijksmuseum van Natuurlijke Historie and "ZMA Coel." for the former Zoological Museum, University of Amsterdam.

\section{Results and discussion}

Helioseris cucullata was observed during 14 of 36 dives (40\%) in a depth range of $12-30 \mathrm{~m}$. All specimens were found at the sheltered Caribbean side of St. Eustatius, where most dive sites were located (Hoeksema and Van Moorsel 2016). On average, two to three specimens (maximum five) were observed on dives where the species was present. Three new association 
Table 1 Old and new records of West Atlantic coral species, among them Helioseris cucullata, recorded as host of Spirobranchus giganteus, Vermiliopsis sp., Opecarcinus hypostegus, Megatrema madreporarum, and Copepoda

\begin{tabular}{|c|c|c|c|c|c|}
\hline & S. giganteus & Vermiliopsis & O. hypostegus & M. madreporarum & Copepoda \\
\hline \multicolumn{6}{|l|}{ Acroporidae } \\
\hline Acropora palmata (Lamarck, 1816) & $\mathrm{a}, \mathrm{f}$ & - & - & - & $\mathrm{h}, \mathrm{j}$ \\
\hline \multicolumn{6}{|l|}{ Agariciidae } \\
\hline Agaricia agaricites (Linnaeus, 1758) & $\mathrm{a}$ & - & $\mathrm{c}$ & $\mathrm{d}, \mathrm{f}, \mathrm{g}$ & $\mathrm{n}$ \\
\hline Agaricia fragilis Dana, 1848 & - & - & $\mathrm{c}$ & $\mathrm{g}$ & $\mathrm{n}$ \\
\hline Agaricia grahamae Wells, 1973 & - & - & $\mathrm{c}$ & $\mathrm{f}$ & - \\
\hline Agaricia humilis Verrill, 1901 & $\mathrm{a}$ & - & $\mathrm{c}$ & - & - \\
\hline Agaricia lamarcki Milne Edwards and Haime, 1851 & $\mathrm{a}$ & - & $\mathrm{c}$ & f, g & $\mathrm{n}$ \\
\hline Helioseris cucullata (Ellis and Solander, 1786) & + & + & + & $\mathrm{f}$ & - \\
\hline \multicolumn{6}{|l|}{ Astrocoeniidae } \\
\hline Stephanocoenia intersepta (Lamarck, 1816) & $\mathrm{a}$ & $\mathrm{b}$ & - & $\mathrm{f}$ & $\mathrm{n}$ \\
\hline \multicolumn{6}{|l|}{ Dendrophylliidae } \\
\hline Rhizopsammia goesi (Lindström, 1877) & $\mathrm{a}$ & - & - & - & - \\
\hline Tubastraea coccinea Lesson, 1829 & $\mathrm{a}$ & $\mathrm{a}$ & - & - & $\mathrm{n}$ \\
\hline \multicolumn{6}{|l|}{ Meandrinidae } \\
\hline Dendrogyra cylindrus Ehrenberg, 1834 & $\mathrm{a}$ & - & - & - & $\mathrm{h}, \mathrm{n}$ \\
\hline Dichocoenia stokesii Milne Edwards and Haime, 1848 & $\mathrm{a}$ & - & - & $\mathrm{f}$ & $\mathrm{h}, \mathrm{n}$ \\
\hline Eusmilia fastigiata (Pallas, 1766) & a & - & - & - & $\mathrm{h}, \mathrm{n}$ \\
\hline Meandrina danae (Milne Edwards and Haime, 1848) & - & - & - & - & $\mathrm{n}$ \\
\hline Meandrina meandrites (Linnaeus, 1758) & $\mathrm{a}$ & - & - & - & $\mathrm{h}, \mathrm{j}, \mathrm{l}, \mathrm{n}$ \\
\hline \multicolumn{6}{|l|}{ Merulinidae } \\
\hline Orbicella annularis (Ellis and Solander, 1786) & $\mathrm{a}$ & - & - & - & $\mathrm{h}, \mathrm{k}, 1$ \\
\hline Orbicella faveolata (Ellis and Solander, 1786) & $\mathrm{a}$ & - & - & - & $\mathrm{n}$ \\
\hline Orbicella franksi (Gregory, 1895) & $\mathrm{a}$ & - & - & - & $\mathrm{n}$ \\
\hline \multicolumn{6}{|l|}{ Montastraeidae } \\
\hline Montastraea cavernosa (Linnaeus, 1767) & $\mathrm{a}$ & - & - & - & $\mathrm{h}, \mathrm{i}, \mathrm{j}, \mathrm{l}, \mathrm{n}$ \\
\hline \multicolumn{6}{|l|}{ Mussidae } \\
\hline Colpophyllia natans (Houttuyn, 1772) & $\mathrm{a}$ & - & - & - & $\mathrm{h}, \mathrm{j}, \mathrm{k}$ \\
\hline Favia fragum (Esper, 1795) & - & - & - & - & $\mathrm{k}$ \\
\hline Isophyllia rigida (Dana, 1846) & - & - & - & - & $\mathrm{n}$ \\
\hline Isophyllia sinuosa (Ellis and Solander, 1786) & - & - & - & - & $\mathrm{n}$ \\
\hline Manicina areolata (Linnaeus, 1758) & - & - & - & - & $\mathrm{h}, \mathrm{k}, \mathrm{n}$ \\
\hline Mycetophyllia aliciae Wells, 1973 & - & - & - & - & $\mathrm{n}$ \\
\hline Mycetophyllia ferox Wells, 1973 & - & - & - & $\mathrm{f}$ & - \\
\hline Mycetophyllia lamarckiana Wells, 1973 & - & - & - & - & $\mathrm{j}, \mathrm{m}$ \\
\hline Mussa angulosa (Pallas, 1766) & - & - & - & - & $\mathrm{n}$ \\
\hline Mussismilia hispida (Verrill, 1901) & - & - & $? \mathrm{c}$ & - & - \\
\hline Diploria labyrinthiformis (Linnaeus, 1758) & a & - & - & - & $\mathrm{h}$ \\
\hline Pseudodiploria clivosa (Ellis and Solander, 1786) & - & - & - & - & $\mathrm{h}, \mathrm{j}, \mathrm{k}, \mathrm{n}$ \\
\hline Pseudodiploria strigosa (Dana, 1846) & $\mathrm{a}$ & - & - & - & $\mathrm{h}, \mathrm{j}, \mathrm{k}, \mathrm{n}$ \\
\hline \multicolumn{6}{|l|}{ Oculinidae } \\
\hline Oculina valenciennesi Milne Edwards and Haime, 1850 & $\mathrm{a}$ & - & - & - & - \\
\hline \multicolumn{6}{|l|}{ Pocilloporidae } \\
\hline Madracis auretenra Locke, Weil \& Coates, 2007 & $\mathrm{a}$ & - & - & $\mathrm{f}$ & $\mathrm{n}$ \\
\hline Madracis decactis (Lyman, 1859) & $\mathrm{a}$ & - & - & $e, f$ & - \\
\hline Madracis formosa Wells, 1973 & $\mathrm{a}$ & - & - & - & - \\
\hline Madracis pharensis (Heller, 1868) & $\mathrm{a}$ & - & - & - & - \\
\hline
\end{tabular}


Table 1 (continued)

\begin{tabular}{|c|c|c|c|c|c|}
\hline & S. giganteus & Vermiliopsis & O. hypostegus & M. madreporarum & Copepoda \\
\hline \multicolumn{6}{|l|}{ Poritidae } \\
\hline Porites astreoides Lamarck, 1816 & $\mathrm{a}$ & - & - & - & $\mathrm{n}$ \\
\hline Porites branneri Rathbun, 1887 & $\mathrm{a}$ & - & - & - & - \\
\hline Porites divaricata Le Sueur, 1820 & - & - & - & - & $\mathrm{n}$ \\
\hline Porites furcata Lamarck, 1816 & $\mathrm{a}$ & - & - & - & $\mathrm{n}$ \\
\hline Porites porites (Pallas, 1766) & $\mathrm{a}$ & - & - & - & - \\
\hline \multicolumn{6}{|l|}{ Siderastreidae } \\
\hline Siderastrea siderea (Ellis and Solander, 1768) & $\mathrm{a}$ & - & $? \mathrm{c}$ & - & $\mathrm{n}$ \\
\hline Siderastrea stellata (Verrill, 1868) & - & - & $? \mathrm{c}$ & - & - \\
\hline \multicolumn{6}{|l|}{ Scleractinia incertae sedis } \\
\hline Solenastrea bournoni Milne Edwards and Haime, 1849 & - & - & - & - & $\mathrm{n}$ \\
\hline
\end{tabular}

New host records are marked by +. Absent records (presumed) by -. Previous host records are from (a) Hoeksema and Ten Hove (2016); (b) Martin and Britayev (1998); (c, ? c = doubtful record) Van der Meij (2014); (d) Ross and Newman (1973); (e) Bacon et al. (1984); (f) Scott (1987); (g) Young (1988); (h) Stock (1975a); (i) Stock (1975b); (j) Herriott and Immermann (1979); (k) Stock (1987); (I) Stock (1989); (m) Varela et al. (2005); (n) Ivanenko (2016)

records with $H$. cucullata were discovered (Table 1): the serpulids Spirobranchus giganteus (Pallas, 1766) $(n=1)$ and Vermiliopsis sp. $(n=1)$ (Fig. 1), and the cryptochirid Opecarcinus hypostegus (Shaw and Hopkins, 1977) $(n=1)$. A second association record (first by Scott 1987) is reported for the coral barnacle Megatrema madreporarum (Bosc, 1812), in this case with up to 20 specimens per host (Fig. 2). Although 26 reef coral species were observed hosting copepods (Table 1; Ivanenko 2016) they were not found in H. cucullata. One $H$. cucullata colony has been observed in association with a sponge of the species Agelas conifer (Schmidt, 1870), showing the same kind of interactive behaviour as Agaricia corals, viz. overgrowing the sponge (García-Hernández et al. 2016). Scleractinia-associated hydroids were discovered for the first time in the Atlantic during the St. Eustatius expedition in 2015 (Montano et al. 2016), but not on H. cucullata. They could have been overlooked due to their small sizes $(\sim 1 \mathrm{~mm}$; see, for example, Montano et al. 2015a, 2016).

Only a few new associations were recorded. Although Spirobranchus giganteus appears not to have been recorded from St. Eustatius before (Ten Hove 1970), during the 2015 survey it was common on various host coral species. Only a single specimen was found in association with $H$. cucullata (Fig. 1a, b), representing the 29th host record (Table 1). This is consistent with the finding that this serpulid is a common host generalist (Hunte et al. 1990; Hoeksema and Ten Hove 2016). Earlier, this association was probably not reported because this host is usually less common than other corals (e.g., Scott 1987) and virtually absent in shallow waters ( $<10 \mathrm{~m}$ depth). Other new host discoveries for Spirobranchus were also made by targeting various potential host species (Hoeksema and Ten Hove 2014, 2016; Hoeksema et al. 2015; Van der Schoot et al. 2016).
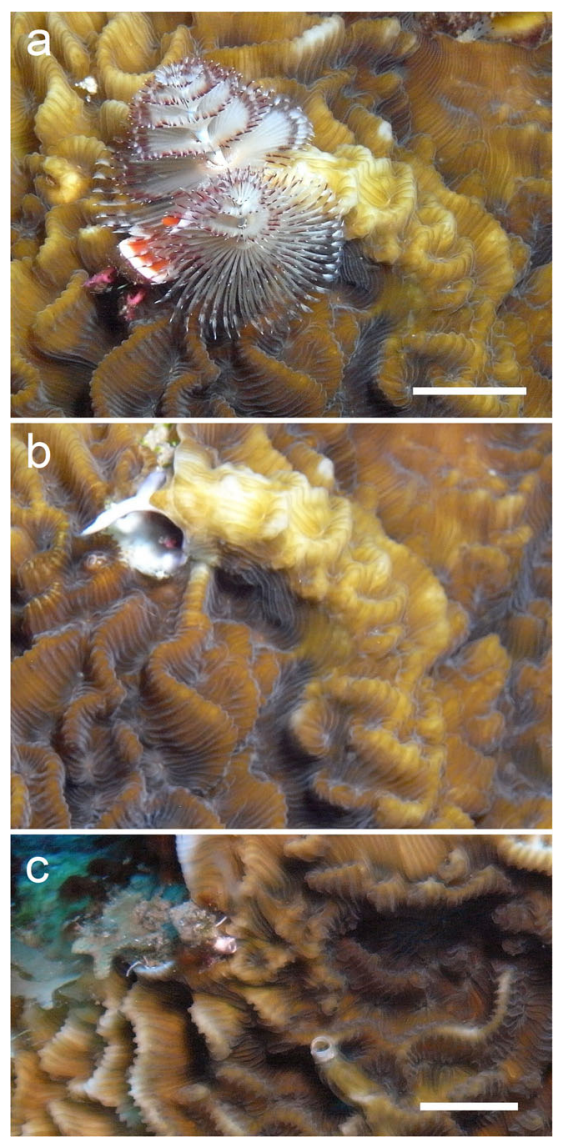

Fig. 1 Helioseris cucullata host corals with serpulid worms at St. Eustatius. a Extended Spirobranchus giganteus worm showing twin spiral branchiae and pink antler-shaped opercular spines. b Same worm contracted, showing the coral-embedded tube and a large spine at its opening. c Two tubes of Vermiliopsis sp., one growing from the lower side with opening at the corallum margin and one embedded in the coral with opening in the centre. Scale bars: $0.5 \mathrm{~cm}$ 
Fig. 2 Helioseris cucullata host coral with associated crustacean fauna at St. Eustatius. a Entire coral. b Close-up showing barnacles, Megatrema madreporarum. c Close-up of dwelling occupied by a gall crab, Opecarcinus hypostegus. Scale bar (for $\mathbf{b}$ and c): $0.5 \mathrm{~cm}$

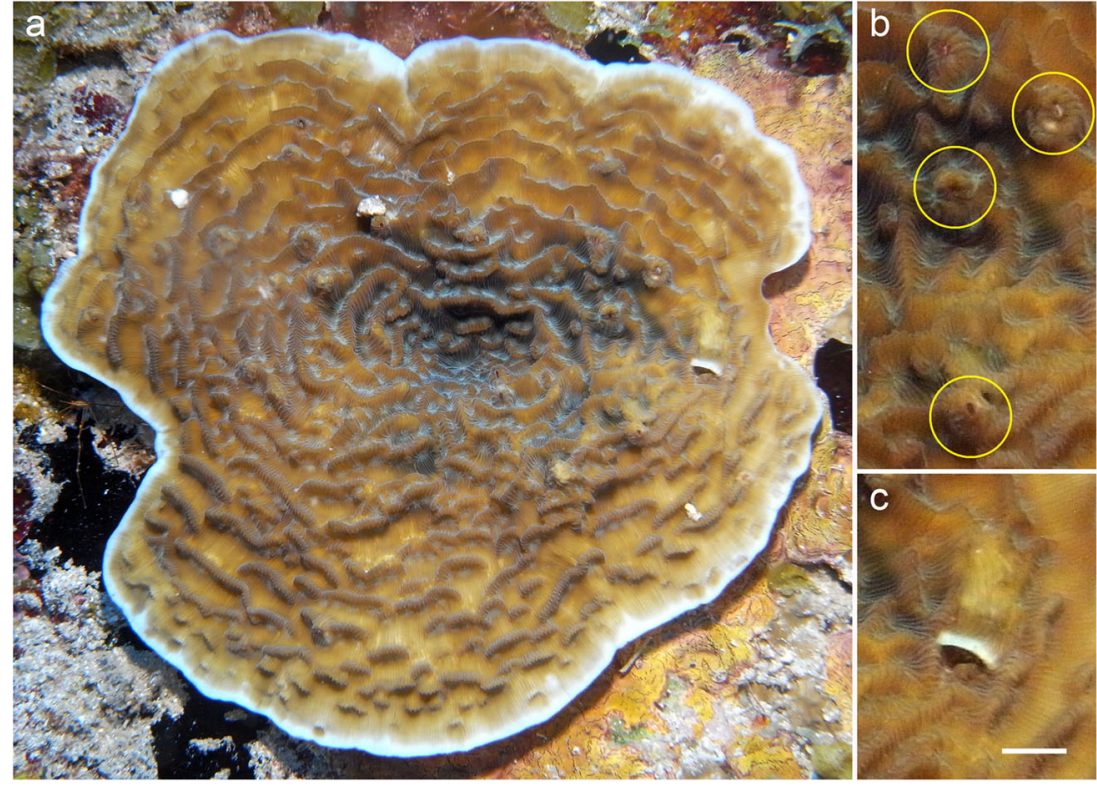

One specimen of $H$. cucullata showed an association with two individuals of another serpulid, an unidentified Vermiliopsis sp. (Fig. 1c). The radioles were retracted inside the tubes, but the genus was identified based on its lightbrown chitinous (horn-like) operculum cap (Ten Hove and Kupriyanova 2009). One species, Vermiliopsis annulata (Schmarda, 1861), is common in the Caribbean and was also found during the St. Eustatius expedition, but not always associated with corals (e.g., Ten Hove and San Martín 1995; Bastida-Zavala 2012; Hepburn et al. 2015). Observations of Vermiliopsis spp. in corals are rare (Table 1), and in literature reviews of coral-associated polychaetes they are usually not mentioned (Stella et al. 2011; Molodtsova et al. 2016). So far it only appeared to have been reported as an associate of Stephanocoenia intersepta (Martin and Britayev 1998; Humann et al. 2013) and the invasive Tubastraea coccinea (Lesson, 1829) (Hoeksema and Ten Hove 2016). These serpulids prefer downward-facing substrates (Hepburn et al. 2015), and are therefore most likely found at the undersurface of corals (e.g., Hoeksema and Ten Hove 2016). One individual in the present study was primarily attached to the lower side of the coral margin, while the other penetrated the coral's upper surface (Fig. 1c). In H. cucullata no specimens were observed of the Caribbean coral-dwelling serpulid Pseudovermilia madracicola Ten Hove, 1989, so far only recorded from Madracis decactis and Madracis pharensis (Ten Hove 1989). During the survey at St. Eustatius, this serpulid with red radioles was observed in specimens of $M$. pharensis and Madracis senaria Wells, 1973.

Coral gall crabs are considered part of the reef's cryptofauna because they are small and reside in dwellings on the coral surface. They are easily overlooked but may appear to be abundant when received special focus in field surveys (Hoeksema and Van der Meij 2013; Van der Meij and Hoeksema 2013). At St. Eustatius, one non-ovigerous Opecarcinus hypostegus female was found in H. cucullata at $30 \mathrm{~m}$ depth (Fig. 2a, c). Previously, this crab was reported from eight host coral species, but three of these records are doubtful (Table 1). New records show that $O$. hypostegus probably only occurs in species belonging to the coral family Agariciidae. Earlier records from the Siderastreidae should probably be attributed to the recently described cryptochirid species Kroppcarcinus siderastreicola Badaro, Castro, and Johnson, 2012 (Van der Meij 2014; Van der Meij et al. 2015a). Again, the relatively low abundance of the host at other localities may have prevented earlier discoveries of this association (Van der Meij 2014). In Agaricia hosts, this crab appears to be most abundant at lower reef slopes (Van Tienderen and Van der Meij 2016), and occurs even at $60 \mathrm{~m}$ depth (Van der Meij et al. 2015a). The present gall crab observation is consistent with our hypothesis that a specific search for associated fauna in potential host corals may result in new association records (see also Van der Meij 2014, 2015a, 2015b; Van der Meij et al. 2015b).

Coral-inhabiting barnacles are common on reefs, and therefore the second record of an association between Megatrema madreporarum and H. cucullata, after Scott's (1987), is not surprising (Fig. 2b), considering that few studies on these barnacles have been performed in the Caribbean. Six H. cucullata corals in the coral collection of Naturalis Biodiversity Center also contain such barnacles. Out of eight colonies collected at Curaçao in 1974 and 1977, four hosted barnacles: RMNH Coel. 8570, 13783 — two specimens, ZMA Coel. 7522. Two more hosts were collected in 1972 close to St. Eustatius: at Saba (RMNH Coel. 8569) and at Saba Bank (RMNH Coel. 8573). Apparently, these H. cucullata specimens were overlooked in the collection, 
since they were not recorded in the expedition report (Van der Land 1977). These results confirm the importance of reference collections in baseline studies (Hoeksema et al. 2011).

The taxonomy of Megatrema madreporarum is described in detail by Ross and Newman (1973). They present a clear illustration of several specimens (as Boscia) in an Agaricia coral from Key West, Florida. In total, M. madreporarum has been reported from ten host species, among them H. cucullata and four Agaricia spp. (Table 1). An extensive overview of Caribbean coral barnacles and their hosts is not available yet (Table 1; Ross and Newman 2002). Recent studies have shed more light on the phylogenetic relations of coral-dwelling barnacles, but these included only three Atlantic species and not Megatrema (Malay and Michonneau 2014; Simon-Blecher et al. 2016).

No associated copepods were found in H. cucullata. Also, no previous records are known for this coral (Cheng et al. 2016; Walter and Boxshall 2016), whereas 26 other scleractinians in the present survey appeared to serve as host for copepods out of a total of 32 host corals for the whole Caribbean (Table 1). Three of these scleractinians (Agaricia spp.) belong to the same family (Agariciidae) as Helioseris. The 21 coral-dwelling copepod species consisted of ten endosymbionts (Poecilostomatoida: Corallovexiidae) (Stock 1975a; Butter 1979; Herriott and Immermann 1979) and 11 ectosymbionts (Siphotostomatoida: Asterocheridae) (Stock 1975b, 1987, 1989; Varela et al. 2005; Kim 2010).

The present study shows that surveys targeting specific coral species can result in new association records, in this case involving serpulid worms and a coral gall crab as associates of H. cucullata. Due to the approach followed in the present study, by dealing specifically with the associated fauna of a single host coral species, $H$. cucullata appears to be richer in associates than many other Caribbean coral species (Table 1). This probably reflects the additional research effort executed in this study.

Little is known about differences in possible biological defense mechanisms among coral species. Such mechanisms might explain why some corals are more hospitable hosts than others, or behave differently (adaptive, aggressive, evasive, submissive, or neutrally tolerant) when they come in contact with other organisms (Chadwick and Morrow 2011; Hoeksema and De Voogd 2012; Hoeksema et al. 2014; Elliott et al. 2016; García-Hernández et al. 2016; Hammerman and García-Hernández 2016). Other associations may simply occur at greater depths and may require other methods than use of SCUBA for their discovery or for examination of their lower depth ranges (e.g., Van der Meij et al. 2015a). Many interspecific associations may remain undiscovered, particularly when hosts are increasingly threatened with extinction (see Carpenter et al. 2008; Huang 2012; Curnick et al. 2015). Attention to the number of coral associates per host coral (Scott 1987; Hoeksema et al. 2012) may therefore offer valuable information in studies of coralreef conservation status (Stella et al. 2011).
Acknowledgments We want to thank staff of St. Eustatius Marine Parks (STENAPA), Caribbean Netherlands Science Institute (CNSI) and Scubaqua Dive Centre providing logistic support. Fieldwork participation of V.N. Ivanenko was funded through a Martin Fellowship from Naturalis Biodiversity Centre. His laboratory study of Caribbean copepods was supported by the Russian Science Foundation (\#14-50-00029). Finally, we are very grateful to two anonymous reviewers for their constructive comments.

Open Access This article is distributed under the terms of the Creative Commons Attribution 4.0 International License (http:// creativecommons.org/licenses/by/4.0/), which permits unrestricted use, distribution, and reproduction in any medium, provided you give appropriate credit to the original author(s) and the source, provide a link to the Creative Commons license, and indicate if changes were made.

\section{References}

Alamaru A, Brokovich E, Loya Y (2016) Four new species and three new records of benthic ctenophores (Family: Coeloplanidae) from the Red Sea. Mar Biodivers 46:261-279. doi:10.1007/s12526-0150362-4

Aronson R, Bruckner A, Moore J, Precht B, Weil E (2008) Helioseris cucullata. The IUCN Red List of Threatened Species 2008: e.T133522A3785002. doi:10.2305/IUCN.UK.2008.RLTS. T133522A3785002.en. Downloaded on 19 Aug 2016

Bacon PR, Hubbard R, Southward AJ (1984) New records of cirripedes from Trinidad and Tobago. Stud Fauna Curaçao Caribb Is 67:77-91

Bak RPM (1975) Ecological aspects of the distribution of reef corals in the Netherlands Antilles. Bijdr Dierk 45:181-190

Bastida-Zavala R (2012) Serpula and Spiraserpula (Polychaeta, Serpulidae) from the Tropical Western Atlantic and Gulf of Guinea. ZooKeys 198:1-23. doi:10.3897/zookeys.198.3030

Bongaerts P, Frade PR, Ogier JJ, Hay KB, van Bleijswijk J, Englebert N, Vermeij MJA, Bak RPM, Visser PM, Hoegh-Guldberg O (2013) Sharing the slope: depth partitioning of agariciid corals and associated Symbiodinium across shallow and mesophotic habitats $(2-60 \mathrm{~m})$ on a Caribbean reef. BMC Evol Biol 13:205. doi:10.1186/1471-2148-13-205

Bos AR (2012) Fishes (Gobiidae and Labridae) associated with the mushroom coral Heliofungia actiniformis (Scleractinia: Fungiidae) in the Philippines. Coral Reefs 31:133. doi:10.1007/s00338-011-0834-3

Bos AR, Hoeksema BW (2015) Cryptobenthic fishes and co-inhabiting shrimps associated with the mushroom coral Heliofungia actiniformis (Fungiidae) in the Davao Gulf, Philippines. Environ Biol Fish 98:1479-1489. doi:10.1007/s10641-014-0374-0

Brinkmann BW, Fransen CHJM (2016) Identification of a new stony coral host for the anemone shrimp Periclimenes rathbunae Schmitt, 1924 with notes on the host-use pattern. Contrib Zool 85: 437-456

Butter ME (1979) Biology and infestation rate of Corallonoxia longicauda, an endoparasitic copepod of the West Indian reef coral Meandrina meandrites. Bijdr Dierk 48:141-155

Carpenter KE, Abrar M, Aeby G, Aronson RB, Banks S et al (2008) One-third of reef-building corals face elevated extinction risk from climate change and local impacts. Science 321:560-563. doi:10.1126/science. 1159196

Chadwick NE, Morrow KM (2011) Competition among sessile organisms on coral reefs. In: Dubinsky Z, Stambler N (eds) Coral reefs: an ecosystem in transition. Springer, Dordrecht, pp 347-371. doi:10.1007/978-94-007-0114-4 20

Cheng YR, Mayfield AB, Meng PJ, Dai CF, Huys R (2016) Copepods associated with scleractinian corals: a worldwide checklist and a case study of their impact on the reef-building coral Pocillopora 
damicornis (Linnaeus, 1758) (Pocilloporidae). Zootaxa 4174:291345. doi:10.11646/zootaxa.4174.1.20

Curnick DJ, Head CEI, Huang D, Crabbe MJC, Gollock M et al (2015) Setting evolutionary-based conservation priorities for a phylogenetically data-poor taxonomic group (Scleractinia). Anim Conserv 18: 303-312. doi:10.1111/acv.12185

Duriš Z, Lin CW (2016) The 'scorpion shrimp', a new species of the genus Metapontonia (Crustacea: Decapoda: Palaemonidae) from Taiwan, with new generic record from Papua New Guinea. Zootaxa 4138:474-490. doi:10.11646/zootaxa.4138.3.3

Elliott J, Patterson M, Vitry E, Summer N, Miternique C (2016) Morphological plasticity allows coral to actively overgrow the aggressive sponge Terpios hoshinota (Mauritius, southwestern). Mar Biodivers 46:489-493. doi:10.1007/s12526-015-0370-4

Fransen CHJM, Rauch C (2013) Hamodactylus macrophthalmus spec. nov., a new coral-associated pontoniine shrimp (Decapoda, Caridea, Palaemonidae) from Indonesia. Zootaxa 3635:286-296. doi:10.11646/zootaxa.3635.3.8

García-Hernández JE, Van Moorsel GWNM, Hoeksema BW (2016) Lettuce corals overgrowing tube sponges at St. Eustatius, Dutch Caribbean. Mar Biodivers. doi:10.1007/s12526-016-0467-4

Gittenberger A, Gittenberger E (2011) Cryptic, adaptive radiation of endoparasitic snails: sibling species of Leptoconchus (Gastropoda: Coralliophilidae) in corals. Org Divers Evol 11:21-41. doi:10.1007/s13127-011-0039-1

Gittenberger A, Hoeksema BW (2013) Habitat preferences of coralassociated wentletrap snails (Gastropoda: Epitoniidae). Contrib Zool 82:1-25

Hammerman NM, García-Hernández JE (2016) The sponge Xestospongia muta offers shelter to the stony coral Madracis auretenra (Northwest Puerto Rico). Mar Biodivers. doi:10.1007/s12526-016-0574-2

Hepburn LJ, Blanchon P, Murphy G, Cousins L, Perry CT (2015) Community structure and palaeoecological implications of calcareous encrusters on artificial substrates across a Mexican Caribbean reef. Coral Reefs 34:189-200. doi:10.1007/s00338-014-1227-1

Herriott AB, Immermann FW (1979) A preliminary report on copepods endoparasitic in stony corals of St. Croix, US Virgin Islands. Crustaceana 36:166-172

Hoeksema BW (2016) Marine biodiversity survey of St. Eustatius, Dutch Caribbean, 2015. Naturalis Biodiversity Center, Leiden

Hoeksema BW, de Voogd NJ (2012) On the run: free-living mushroom corals avoiding interaction with sponges. Coral Reefs 31:455-459. doi:10.1007/s00338-011-0856-x

Hoeksema BW, ten Hove HA (2014) First record of a christmas tree worm in a mushroom coral (Loyalty Islands, Southwest Pacific). Coral Reefs 33:717. doi:10.1007/s00338-014-1175-9

Hoeksema BW, ten Hove HA (2016) The invasive sun coral Tubastraea coccinea hosting a native Christmas tree worm at Curaçao, Dutch Caribbean. Mar Biodivers. doi:10.1007/s12526-016-0472-7

Hoeksema BW, van der Meij SET (2013) Gall crab city: an aggregation of endosymbiotic crabs inhabiting a colossal colony of Pavona clavus. Coral Reefs. doi:10.1007/s00338-012-0954-4

Hoeksema BW, van Moorsel GWNM (2016) Stony corals of St. Eustatius. In: Hoeksema BW (ed) Marine biodiversity survey of St, Eustatius, Dutch Caribbean, 2015. Naturalis Biodiversity Center, Leiden, pp 32-37

Hoeksema BW, van der Land J, van der Meij SET, van Ofwegen LP, Reijnen BT, van Soest RWM, de Voogd NJ (2011) Unforeseen importance of historical collections as baselines to determine biotic change of coral reefs: the Saba Bank case. Mar Ecol 32:135-141. doi:10.1111/j.1439-0485.2011.00434.x

Hoeksema BW, van der Meij SET, Fransen CHJM (2012) The mushroom coral as a habitat. J Mar Biol Assoc UK 92:647663. doi:10.1017/S0025315411001445
Hoeksema BW, Waheed Z, Alamaru A (2013) Out of sight: aggregations of epizoic comb jellies underneath mushroom corals. Coral Reefs 32:1065. doi:10.1007/s00338-013-1078-1

Hoeksema BW, Dekker F, de Voogd NJ (2014) Free-living mushroom corals strike back by overtopping a coral-killing sponge. Mar Biodivers 44:3-4. doi:10.1007/s12526-013-0188-x

Hoeksema BW, Lau YW, ten Hove HA (2015) Octocorals as secondary hosts for Christmas tree worms at Curaçao. Bull Mar Sci 91:489_ 490. doi:10.5343/bms.2015.1049

Huang D (2012) Threatened reef corals of the world. PLoS ONE 7: e34459. doi:10.1371/journal.pone.0034459

Huang D, Hoeksema BW, Amri AY, Ang PO, Chen CA, Huang H, Lane DJW, Licuanan WY, Vibol O, Vo ST, Yeemin T, Chou LM (2016) Conservation of reef corals in the South China Sea based on species and evolutionary diversity. Biodivers Conserv 25:331-344. doi:10.1007/s10531-016-1052-7

Hughes TP, Tanner JE (2000) Recruitment failure, life histories, and longterm decline of Caribbean corals. Ecology 81:2250-2263. doi: $10.2307 / 177112$

Humann P, DeLoach N (2013) Reef coral identification: Florida, Caribbean, Bahamas, 3rd edn. New World Publications, Jacksonville

Humann P, DeLoach N, Wilk L (2013) Reef creature identification: Florida, Caribbean, Bahamas, 3rd edn. New World Publications, Jacksonville

Hunte W, Conlin BE, Marsden JR (1990) Habitat selection in the tropical polychaete Spirobranchus giganteus. I. Distribution on corals. Mar Biol 104:87-92. doi:10.1007/BF01313161

Ivanenko VN (2016) Symbiotic copepods associated with invertebrates at St. Eustatius. In: Hoeksema BW (ed) Marine biodiversity survey of St. Eustatius, Dutch Caribbean, 2015. Naturalis Biodiversity Center, Leiden, pp 60-64

Ivanenko VN, Moudrova SV, Bouwmeester J, Berumen ML (2014) First report of tubular corallites on Stylophora caused by a symbiotic copepod crustacean. Coral Reefs 33:637. doi:10.1007/s00338-014-1186-6

Jaap WC (2015) Stony coral (Milleporidae and Scleractinia) communities in the eastern Gulf of Mexico: a synopsis with insights from the Hourglass collections. Bull Mar Sci 91:207-253. doi:10.5343/bms.2014.1049

Kahng SE, Garcia R, Spalding HL, Brokovich E, Wagner D, Weil E, Hinderstein L, Toonen RJ (2010) Community ecology of mesophotic coral reef ecosystems. Coral Reefs 29:255-275. doi:10.1007/s00338-010-0593-6

Kim IH (2010) Siphonostomatoid Copepoda (Crustacea) associated with invertebrates from tropical waters. Kor J Syst Zool Spec Issue 8:1-176

Kitahara MV, Stolarski J, Cairns SD, Benzoni F, Stake JL, Miller DJ (2012) The first modern solitary Agariciidae (Anthozoa, Scleractinia) revealed by molecular and microstructural analysis. Invertebr Syst 26:303-315. doi:10.1071/IS11053

Kitahara MV, Fukami H, Benzoni F, Huang D (2016) The new systematics of Scleractinia: integrating molecular and morphological evidence. In: Goffredo S, Dubinsky Z (eds) The Cnidaria, past, present and future. Springer, Switzerland, pp 41-59. doi:10.1007/978-3319-31305-4 4

Malay MCD, Michonneau F (2014) Phylogenetics and morphological evolution of coral-dwelling barnacles (Balanomorpha: Pyrgomatidae). Biol J Linn Soc 113:162-179. doi:10.1111/bij.12315

Martin D, Britayev TA (1998) Symbiotic polychaetes: review of known species. Oceanogr Mar Biol Annu Rev 36:217-340

Miller A (1981) Cnidarian prey of the snails Coralliophila abbreviata and C. caribaea (Gastropoda: Muricidae) in Discovery Bay, Jamaica. Bull Mar Sci 31:932-934

Miller M, Williams DE, Huntington BE, Piniak GA, Vermeij MJA (2016) Decadal comparison of a diminishing coral community: a study using demographics to advance inferences of community status. Peer J 4:e1643. doi:10.7717/peerj.1643 
Molodtsova TN, Britayev TA, Martin D (2016) Cnidarians and their polychaete symbionts. In: Goffredo S, Dubinsky Z (eds) The Cnidaria, past, present and future. Springer, Switzerland, pp 387413. doi:10.1007/978-3-319-31305-4 25

Montano S, Arrigoni R, Pica D, Maggioni D, Puce S (2014) New insights into the symbiosis between Zanclea (Cnidaria, Hydrozoa) and scleractinians. Zool Scr 44:92-105. doi:10.1111/zsc.12081

Montano S, Maggioni D, Arrigoni R, Seveso D, Puce S, Galli P (2015a) The hidden diversity of the Zanclea associated with scleractinians revealed by molecular data. PLoS ONE 10:e0133084. doi:10.1371/journal. pone. 0133084

Montano S, Seveso D, Galli P, Puce S, Hoeksema BW (2015b) Mushroom corals as newly recorded hosts of the hydrozoan symbiont Zanclea sp. Mar Biol Res 11:773-779. doi:10.1080/17451000.2015.1009467

Montano S, Galli P, Hoeksema BW (2016) First record from the Atlantic: a Zanclea-scleractinian association at St. Eustatius, Dutch Caribbean. Mar Biodivers. doi:10.1007/s12526-015-0432-7

Potkamp G (2016) Host-related divergence in Coralliophila spp. at Curaçao. MSc thesis, University of Amsterdam

Risk MJ, Heikoop JM, Edinger EN, Erdmann MV (2001) The assessment 'toolbox': community-based reef evaluation methods coupled with geochemical techniques to identify sources of stress. Bull Mar Sci 69:443-458

Ross A, Newman WA (1973) Revision of the coral-inhabiting barnacles (Cirripedia, Balanidae). Trans San Diego Soc Nat Hist 17:137-173

Ross A, Newman WA (2002) Coral barnacles: Cenozoic decline and extinction in the Atlantic/East Pacific versus diversification in the Indo-West Pacific. Proc 9th Int Coral Reef Symp 1:135-139

Samimi Namin K, Risk MJ, Hoeksema BW, Zohari Z, Rezai H (2010) Coral mortality and serpulid infestations associated with red tide, in the Persian Gulf. Coral Reefs 29:509. doi:10.1007/s00338-010-0601-x

Santodomingo N, Reyes J, Gracia A, Martínez A, Ojeda G, García C (2007) Azooxanthellate Madracis coral communities off San Bernardo and Rosario Islands (Colombian Caribbean). Bull Mar Sci 81:273-287

Scaps P, Denis V (2008) Can organisms associated with live scleractinian corals be used as indicators of coral reef status? Atoll Res Bull 566:1-18

Scott PJB (1987) Associations between corals and macro-infaunal invertebrates in Jamaica, with a list of Caribbean and Atlantic coral associates. Bull Mar Sci 40:271-286

Simon-Blecher N, Hosie AM, Guy-Haim T, Chan BKK, Achituv Y (2016) Speciation, phenotypic plasticity, or ontogeny, the case of the genus Galkinius (Pyrgomatidae, Cirripedia, Crustacea). Zool J Linn Soc 176:305-322. doi:10.1111/zoj.12314

Stella JS, Pratchett MS, Hutchings PA, Jones GP (2011) Coralassociated invertebrates: diversity, ecology importance and vulnerability to disturbance. Oceanogr Mar Biol Annu Rev 49:43104. doi:10.1201/b11009-3

Stock JH (1975a) Corallovexiidae, a new family of transformed copepods endoparasitic in reef corals. Stud Fauna Curaçao Caribb Is 47:1-45

Stock JH (1975b) Peltomyzon rostratum n. gen., n. sp., a siphonostome cyclopoid copepod associated with the West Indian coral Montastraea. Bull Zool Mus Univ Amst 4:111-117

Stock JH (1987) Copepoda Siphonostomatoida associated with West Indian hermatypic corals 1: Associates of Scleractinia: Faviinae. Bull Mar Sci 40:464-483

Stock JH (1989) Copepoda Siphonostomatoida associated with West Indian hermatypic corals 2: Associates of Scleractinia:
Montastreinae and Trochosmilidae. In: Van der Steen LJ (ed) Studies in honour of Dr. Pieter Wagenaar Hummelinck. Uitgaven Natuurwetenschappelijke Studiekring voor Suriname en de Nederlandse Antillen, Amsterdam, pp 145-169

Ten Hove HA (1970) Serpulinae (Polychaeta) from the Caribbean: I The genus Spirobranchus. Stud Fauna Curaçao Caribb Is 32:1-57

Ten Hove HA (1989) Serpulinae (Polychaeta) from the Caribbean: IV. Pseudovermilia madracicola sp. n., a symbiont of corals. In: Van der Steen LJ (ed) Studies in honour of Dr. Pieter Wagenaar Hummelinck. Uitgaven Natuurwetenschappelijke Studiekring voor Suriname en de Nederlandse Antillen, Amsterdam, pp 135-144

Ten Hove HA, Kupriyanova EK (2009) Taxonomy of Serpulidae (Annelida, Polychaeta): the state of affairs. Zootaxa 2036:1-126

Ten Hove HA, San Martín S (1995) Serpulidae (Polychaeta) procedentes de la I Expedición Cubano-Española a la Isla de la Juventud y Archipiélago de los Canarreos (Cuba). Stud Nat Hist Caribb Reg 72:13-24

Van der Land J (1977) The Saba Bank — a large atoll in the northeastern Caribbean. FAO Fish Rep 200:469-481

Van der Meij SET (2014) Host species, range extensions, and an observation of the mating system of Atlantic shallow-water gall crabs (Decapoda: Cryptochiridae). Bull Mar Sci 90:1001-1010. doi: $10.5343 / \mathrm{bms} .2014 .1017$

Van der Meij SET (2015a) Host relations and DNA reveal a cryptic gall crab species (Crustacea: Decapoda: Cryptochiridae) associated with mushroom corals (Scleractinia: Fungiidae). Contrib Zool 84:39-57

Van der Meij SET (2015b) A new gall crab species (Brachyura, Cryptochiridae) associated with the free-living coral Trachyphyllia geoffroyi (Scleractinia, Merulinidae). ZooKeys 500:61-72. doi:10.3897/zookeys.500.9244

Van der Meij SET, Hoeksema BW (2013) Distribution of gall crabs inhabiting mushroom corals on Semporna reefs, Malaysia. Mar Biodivers 43:53-59. doi:10.1007/s12526-012-0135-2

Van der Meij SET, van Tienderen KM, Hoeksema BW (2015a) A mesophotic record of the gall crab Opecarcinus hypostegus from a Curaçaoan reef. Bull Mar Sci 91:205-206. doi:10.5343/bms.2014.1072

Van der Meij SET, Fransen CHJM, Pasman LR, Hoeksema BW (2015b) Phylogenetic ecology of gall crabs (Cryptochiridae) as associates of mushroom corals (Fungiidae). Ecol Evol 5: 5770-5780. doi:10.1002/ece3.1808

Van der Schoot R, Scott CM, ten Hove HA, Hoeksema BW (2016) Christmas tree worms as epibionts of giant clams at Koh Tao, Gulf of Thailand. Mar Biodivers. doi:10.1007/s12526-015-0439-0

Van Tienderen KM, Van der Meij SET (2016) Occurrence patterns of coral-dwelling gall crabs (Cryptochiridae) over depth intervals in the Caribbean. Peer J 4:e1794. doi:10.7717/peerj.1794

Varela C, Ortiz M, Lalana R (2005) Especie nueva de Asteropontius (Copepoda: Siphonostomatoida) para Cuba. Solenodon 5:6-9

Vermeij MJA, Bakker J, van der Hal N, Bak RPM (2011) Juvenile coral abundance has decreased by more than $50 \%$ in only three decades on a small Caribbean island. Diversity 3:296-307. doi:10.3390/d3030296

Walter TC, Boxshall G (2016) World of Copepods database. Accessed through: World Register of Marine Species at http://www. marinespecies.org/aphia.php?p=taxdetails\&id=348796 on 2016-08-21

Young PS (1988) Recent cnidarian-associated barnacles (Cirripedia, Balanomorpha) from the Brazilian coast. Rev Br Zool 5:353-369 